\title{
Candida bombiphila sp. nov., a new asexual yeast species in the Wickerhamiella clade
}

\author{
Correspondence \\ Michael Brysch-Herzberg \\ Herzberg@students. \\ uni-marburg.de
}

\author{
Michael Brysch-Herzberg ${ }^{1}$ and Marc-André Lachance ${ }^{2}$ \\ ${ }^{1}$ Philipps-University Marburg, Department of Biology, Plant Ecology, Karl-von-Frisch-Straße, \\ 35043 Marburg, Germany \\ ${ }^{2}$ Department of Biology, University of Western Ontario, London, Ontario, Canada N6A 5B7
}

Two yeast strains were isolated from a bumblebee and the honey pots in a bumblebee nest. The strains resembled Wickerhamiella domercqiae physiologically and in their sequences in the D1/D2 domain of the large-subunit rDNA. The genus Wickerhamiella was first described on the basis of the single homothallic species, $W$. domercqiae (van der Walt \& Liebenberg, 1973), and later expanded to include four species from flowers and associated insects (Lachance $e t$ al., 1998, 2000). Together with a number of asexual species in the genus Candida, the genus Wickerhamiella forms a loose monophyletic clade of species that exhibit a relatively low value of DNA relatedness in the D1/D2 region (Lachance et al., 1998). Most species in the clade are associated with insects (Lachance et al., 2000). We now describe Candida bombiphila sp. nov.

The strains were isolated from the proboscis of a Bombus terrestris queen and from the honey pots in a nest of Bombus pascuorum bees. Isolation was performed by direct plating of the honey and by stroking the proboscis of a B. terrestris queen on YM agar (Yarrow, 1998) supplemented with chloramphenicol $\left(100 \mathrm{mg} \mathrm{l}^{-1}\right)$. The yeasts were purified and characterized using standard methods (Yarrow, 1998). Physiological tests were performed using replica plating (Lachance, 1987). Sexual cross-reactivity was evaluated by mixing actively growing cultures on YM agar, $10 \%$ $(\mathrm{w} / \mathrm{w})$ malt-extract agar and on restricted growth medium (Yarrow, 1998). The mixtures were incubated at room temperature and observed periodically with an Axiophot microscope (Zeiss). Images were recorded digitally by the means of a Mega Fire electronic camera (Intas) and

Published online ahead of print on 27 February 2004 as DOI 10.1099/ ijs.0.63139-0.

The GenBank/EMBL/DDBJ accession numbers for the sequences reported in this paper are AJ620185 and AJ620186. optimized for brightness and contrast with the PHOTOSHOP software package (Adobe).

The D1/D2 domain of the large-subunit rDNA was amplified from whole cells and then sequenced as previously described by Lachance et al. (1999). Known sequences for other species were retrieved from GenBank. The DNAMAN package (Lynnon Biosoft) was used to edit and align the sequences with the CLUSTAL W algorithm (Thompson et al., 1994), and to construct trees with the neighbour-joining algorithm.

\section{Latin diagnosis of Candida bombiphila Brysch-Herzberg \& Lachance sp. nov.}

Cultura in extracto malti post dies 3 ad $25^{\circ} \mathrm{C}$ cellulae globosae ad ellipsoideae $(2 \cdot 7-4.0 \times 1 \cdot 9-2.5 \mu \mathrm{m})$, singulae aut binae. Cultura in agaro malti post dies 10 ad $25^{\circ} \mathrm{C}$ cremea et butyrosa. Pseudomycelium et mycelium verum formantur. Glucosum fermentatur. L-Sorbosum, D-ribosum, glycerolum, mannitolum, glucitolum, acidum succinicum, acidum citricum, acidum malicum (lente), acidum gluconicum, glucono$\Delta$-lactonum assimilantur, at non inulinum, sucrosum, raffinosum, melibiosum, galactosum, lactosum, trehalosum, maltosum, melizitosum, methyl $\alpha$-D-glucosidum, amylum, cellobiosum, salicinum, L-rhamnosum, D-xylosum, L-arabinosum, D-arabinosum, methanolum, ethanolum, erythritolum, ribitolum, xylititolum, galactitolum, inositolum, acidum lacticum, 2-keto-D-gluconatum, D-glucosaminum, N-acetylD-glucosaminum, acidum glucuronicum nec hexadecanum. Natrium nitricum, natrium nitrosum, ethylaminum, lysinum et cadaverinum assimilantur. Ad crescentiam vitaminae necessariae sunt. Augmentum ad $37^{\circ} \mathrm{C}$. Habitat Bombus spp. in Germania.

Typus in collectione zymotica Centraalbureau voor Schimmelcultures, Trajectum ad Rhenum, sub no. CBS $9712^{\mathrm{T}}$ deposita est. 


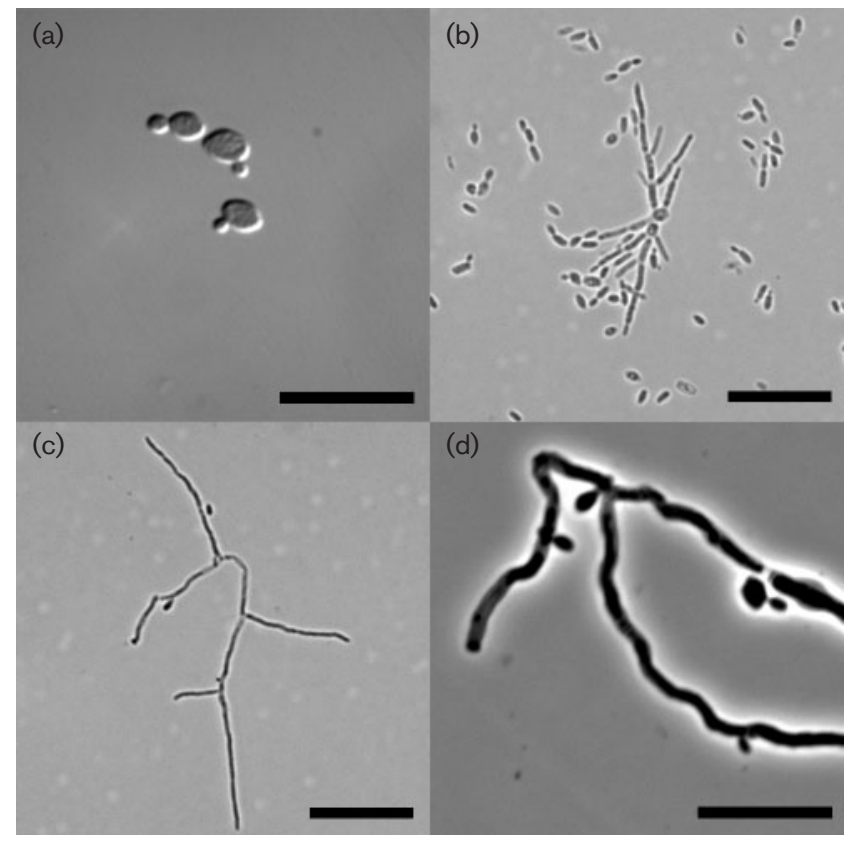

Fig. 1. (a) Differential interference contrast micrograph of budding cells of C. bombiphila (CBS $9712^{\top}$ ) after 3 days in malt-extract broth $(5 \%, w / w)$ at $25^{\circ} \mathrm{C}$. (b) Bright-field micrograph of pseudomycelium after 1 day on YM agar. (c, d) Bright-field (c) and phase-contrast (d) micrographs of true mycelium after 10 days on malt agar $(10 \%, w / w)$ at $25^{\circ} \mathrm{C}$. Bars: $10 \mu \mathrm{m}(\mathrm{a}, \mathrm{d}) ; 20 \mu \mathrm{m}$ (b, c).

\section{Description of Candida bombiphila Brysch-Herzberg \& Lachance sp. nov.}

Candida bombiphila (bom.bi'phi.la. N.L. nom. fem. adj. bombiphila Bombus-loving, in reference to the source of isolation, bumblebees).

In $5 \%(\mathrm{w} / \mathrm{w})$ malt extract after 3 days at $25^{\circ} \mathrm{C}$, the cells are ovoid, single or in parent-bud pairs and $2 \cdot 7-4 \cdot 0 \mu \mathrm{m} \times$ $1 \cdot 9-2 \cdot 5 \mu \mathrm{m}$ (Fig. 1a). On malt agar (10\%, w/w) after 10 days at $25^{\circ} \mathrm{C}$, colonies are cream-coloured, butyrous, convex to umbonate, with a smooth and glossy surface and an entire edge. Occasionally the colonies are convoluted with a lobate edge. Pseudomycelium is formed after 1 day on YM agar at $25{ }^{\circ} \mathrm{C}$ (Fig. 1b). True mycelium is formed after 2 weeks on malt agar $(10 \%, w / w)$ (Fig. 1c, d). Sexual activity has not been observed. Glucose is fermented weakly. Carbon compounds L-sorbose, D-ribose, glycerol, mannitol, glucitol, succinic acid, citric acid, malate (slow), D-gluconate and glucono- $\Delta$-lactone are assimilated; no growth occurs on inulin, sucrose, raffinose, melibiose, galactose, lactose, trehalose, maltose, melezitose, methyl $\alpha$-Dglucoside, starch, cellobiose, salicin, L-rhamnose, D-xylose, L-arabinose, D-arabinose, methanol, ethanol, erythritol, ribitol, xylitol, galactitol, inositol, glucuronate, DL-lactic acid, 2-keto-D-gluconate, D-glucosamine, N-acetyl-Dglucosamine or hexadecane. Nitrate, nitrite, ethylamine, lysine and cadaverine are assimilated. Diazonium blue B reaction is negative. Growth on vitamin-free medium is negative. Growth on amino-acid-free medium is positive. Growth at $37^{\circ} \mathrm{C}$ is positive. Acid production on chalk agar

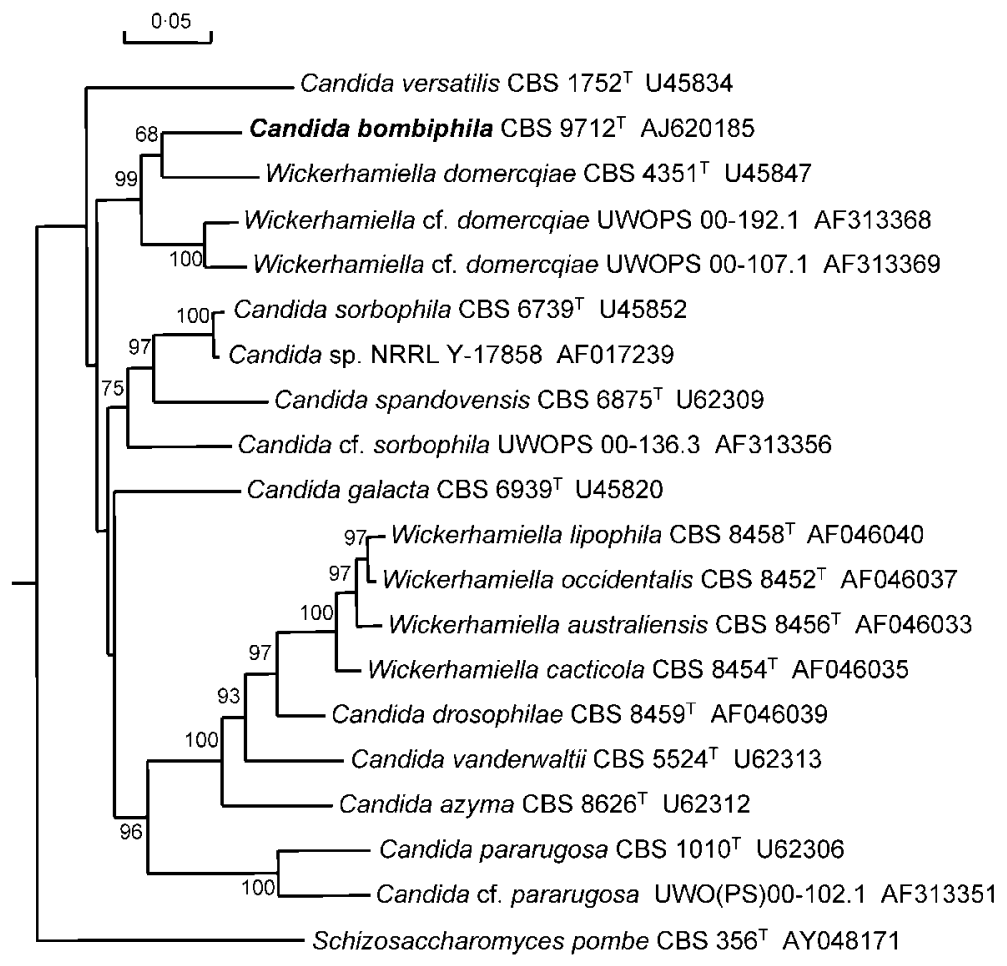

Fig. 2. Neighbour-joining dendrogram of Wickerhamiella and related Candida species based on the D1/D2 variable domains of the large-subunit rRNA gene. Numbers on nodes indicate percentage bootstrap values for 1000 iterations. Accession numbers are shown. The scale bar shows the proportional sequence divergence. 
is slow. Gelatin liquefaction is negative. Casein hydrolysis is weak. Starch formation is negative. Growth on $60 \%$ glucose/yeast extract agar is positive. Growth on YM agar with $5 \%(\mathrm{w} / \mathrm{w}) \mathrm{NaCl}$ is slow and growth on $10 \%(\mathrm{w} / \mathrm{w})$ $\mathrm{NaCl}$ is negative. No growth was observed in the presence of $0 \cdot 01 \%$ cycloheximide.

The habitat is bumblebees and their honey provisions. The type strain has been deposited in the Yeast Division of the Centraalbureau voor Schimmelcultures, Utrecht, the Netherlands, as strain CBS $9712^{\mathrm{T}}$ (=NRRL Y-27640 ${ }^{\mathrm{T}}=$ $\left.\mathrm{MH} 268^{\mathrm{T}}\right)$. It was isolated from the proboscis of a Bombus terrestris queen in early spring. A second strain, CBS 9713 $(=\mathrm{X} 316.5)$, was isolated from the honey provision in a nest of Bombus pascuorum bees in the summer. Both strains were isolated in the New Botanical Garden of Philipps University, Marburg, Germany.

\section{Species delineation and identification}

The D1/D2 sequence of the large-subunit rDNA of the type strain differs from the most closely related species, $W$. domercqiae, by 57 substitutions and three gaps (Fig. 2). Strain CBS 9713 (AJ620186) differs from the type strain by one substitution and one gap. Kurtzman \& Robnett (1998) showed that in most cases distinct species differ by $1 \%$ or more in these sequences; we conclude that our strains represent a novel, well-separated species. The origin and significance of strains with the designation UWOPS in Fig. 2 have been discussed by Lachance et al. (2001). They were included in the analysis for comparison and will be described as part of other studies. The sequence for strain NRRL Y-17858 was deposited in GenBank by Kurtzman \& Robnett (1998).

C. bombiphila can be differentiated from $W$. domercqiae by the inability to grow on ethanol, 2-ketogluconate and $10 \%$ $(\mathrm{w} / \mathrm{w}) \mathrm{NaCl}$, by its growth at $37^{\circ} \mathrm{C}$ and by the ability to ferment glucose. C. bombiphila can be separated from the rest of the clade by the combination of acid production on chalk agar and the ability to grow at $37^{\circ} \mathrm{C}$. The formation of true mycelium is unique to the Wickerhamiella clade. In view of the variability observed in growth characteristics of yeasts in general and the growing number of described species with similar nutritional profiles, definitive identification of the species should rely on determination of the D1/D2 sequence.

\section{Acknowledgements}

We thank R. Fischer for the supply of material for the genetic work and P. Frenzel for access to the microscope. This work was funded by the Deutsche Bundestiftung Umwelt (M.B.-H.) and the Natural Science and Engineering Research Council of Canada (M.-A. L.).

\section{References}

Kurtzman, C. P. \& Robnett, C. J. (1998). Identification and phylogeny of ascomycetous yeasts from analysis of nuclear large subunit (26S) ribosomal DNA partial sequences. Antonie van Leeuwenhoek 73, 331-371.

Lachance, M. A. (1987). Approaches to yeast identification. In Yeast Biotechnology, pp. 33-51. Edited by D. R. Berry, I. Russell \& G. G. Stewart. London: Allen \& Unwin.

Lachance, M. A., Rosa, C. A., Starmer, W. T., Schlag-Edler, B., Barker, J. S. F. \& Bowles, J. M. (1998). Wickerhamiella australiensis, Wickerhamiella cacticola, Wickerhamiella occidentalis, Candida drosophilae and Candida lipophila, five new related yeast species from flowers and associated insects. Int J Syst Bacteriol 48, 1431-1443.

Lachance, M. A., Bowles, J. M., Starmer, W. T. \& Barker, J. S. F. (1999). Kodamaea kakaduensis and Candida tolerans, two new ascomycetous yeast species from Australian Hibiscus flowers. Can J Microbiol 45, 172-177.

Lachance, M. A., Bowles, M. J., Mueller, C. \& Starmer, W. T. (2000). On the biogeography of yeasts in the Wickerhamiella clade and description of Wickerhamiella lipophila sp. nov., the teleomorph of Candida lipophila. Can J Microbiol 46, 1145-1148.

Lachance, M. A., Starmer, W. T., Rosa, C. A., Bowles, J. M., Barker, J. S. F. \& Janzen, D. H. (2001). Biogeography of the yeasts of ephemeral flowers and their insects. FEMS Yeast Res 1, 1-8.

Thompson, J. G., Higgins, D. G. \& Gibson, T. J. (1994). CLUSTAL W: improving the sensitivity of progressive multiple sequence alignment through sequence weighting, position-specific gap penalties and weight matrix choice. Nucleic Acids Res 22, 4673-4680.

van der Walt, J. P. \& Liebenberg, N. V. D. W. (1973). The yeast genus Wickerhamiella gen. nov. (Ascomycetes). Antonie van Leeuwenhoek 39, 121-128.

Yarrow, D. (1998). Methods for the isolation, maintenance and identification of yeasts. In The Yeasts, a Taxonomic Study, 4th edn, pp. 77-100. Edited by C. P. Kurtzman, \& J. W. Fell. Amsterdam: Elsevier. 